NBER WORKING PAPER SERIES

\title{
THE IMPACT OF JOB STRESS ON SMOKING AND QUITTING: EVIDENCE FROM THE HRS
}

\author{
Padmaja Ayyagari \\ Jody L. Sindelar \\ Working Paper 15232 \\ http://www.nber.org/papers/w15232
}

\author{
NATIONAL BUREAU OF ECONOMIC RESEARCH \\ 1050 Massachusetts Avenue \\ Cambridge, MA 02138
}

August 2009

This work was supported by Grant Number RL1AA017542 from the National Institute on Alcohol Abuse and Alcoholism to Yale University and Grant Number R01AG027045 from the National Institute on Aging to Yale University. The views expressed herein are those of the author(s) and do not necessarily reflect the views of the National Bureau of Economic Research.

NBER working papers are circulated for discussion and comment purposes. They have not been peerreviewed or been subject to the review by the NBER Board of Directors that accompanies official NBER publications.

(C) 2009 by Padmaja Ayyagari and Jody L. Sindelar. All rights reserved. Short sections of text, not to exceed two paragraphs, may be quoted without explicit permission provided that full credit, including (c) notice, is given to the source. 
The Impact of Job Stress on Smoking and Quitting: Evidence from the HRS Padmaja Ayyagari and Jody L. Sindelar

NBER Working Paper No. 15232

August 2009

JEL No. I1,I10

\begin{abstract}
$\underline{\text { ABSTRACT }}$
This paper examines the impact of job-related stress on smoking behavior. We use data from the Health and Retirement Study to examine how high job stress affects the probability that smokers quit and the number of cigarettes smoked for current smokers. We include individual fixed effects, which control for time-invariant factors. Occupational fixed effects are also included to control for occupational characteristics other than stress; time dummies control for the secular decline in smoking rates. Using a sample of people who smoked in the previous wave, we find that job stress is positively related to continuing to smoke and to the number of cigarettes smoked for current smokers. The FE results are of greater magnitude and significance than the OLS results suggesting an important omitted variable bias in OLS estimates. It may be that individuals who are able to handle stress or have better self-control are more likely to have high stress jobs and less likely to smoke. We also find that the smoking/stress relationship is neither explained by heterogeneity across individuals in cognitive ability, risk taking preferences or planning horizons nor is it explained by time varying measures that we observe.
\end{abstract}

Padmaja Ayyagari

Yale University

Epidemiology \& Public Health

P.O. Box 208034, 60 College St.

New Haven, CT 06520-8034

padmaja.ayyagari@yale.edu

Jody L. Sindelar

Yale School of Public Health

Yale University School of Medicine

60 College Street, P.O. Box 208034

New Haven, CT 06520-8034

and NBER

jody.sindelar@yale.edu 


\section{Introduction}

Smoking is well-known to be a leading source of preventable morbidity and mortality. In response to the increasing evidence about the smoking-related health risks, to oneself and to others through second-hand smoke, many older individuals who smoked when they were young have quit. Yet about 20\% of the population, including the older population that we examine, continues to smoke. Almost no one starts smoking after age 22. However, former smokers may relapse and start to smoke again while current smokers may change the number of cigarettes that they smoke or may try to quit. Some individuals will cycle in and out of smoking.

Older individuals are at higher risks than other ages for smoking-related health conditions, so they may be even more aware of the realities of adverse health outcomes as they, and other smokers that they know, suffer harmful consequences. For example, Khwaja, Sloan and Chung (2006) find that older smokers change their survival expectations and quit smoking in response to health shocks. However, older individuals may find it more difficult to quit smoking if they have been smoking for a long period of time. Importantly, they may continue to smoke to self-medicate to deal with their stress. Yet, even at older ages, there are health gains to quitting. For example, Taylor et al. (2002) find that male smokers who quit at age 65 gained 1.4 to 2 years of life while female smokers gained 2.7 to 3.7 years. Therefore, it is important to understand the factors that might prevent older individuals from quitting. Further, older smokers are an important group to study because of the financial externalities that they impose on public insurance programs such as Medicare.

Stress presents physiological and psychological challenges to the body and mind; it can be a result of real or perceived challenge to homeostasis (ability to maintain internal stability) (Selye, 1956; McEwen, 2000; Seeman et al, 1997). That stress is a challenge to homeostasis, has been documented in animal (Brandon, 1994; Wills \& Shiffman, 1985) and clinical studies (Sinha, 2001). In response to stress, individuals try to maintain homeostasis through a number of mechanisms, one potential mechanism is to self-medicate by smoking (Koob and Moal, 1997). There is evidence that stress can cause smoking, yet some of this evidence comes from small animal and clinical studies that induce stress in experimental settings (Goeders and Guerin, 1994; 
Sinha, 2001). While these studies can assess causality more directly, the results do not translate well into conclusions about populations of smokers. On the other hand, most studies of large populations are epidemiologic studies that examine only correlations. Further, they often use relatively small non-generalizable samples (e.g. Alexander et al., 1990; Cooper et al., 1989). A large number of the studies examine children only and examine the impact of life events on smoking initiation (e.g. Mates and Allison, 1992; Koval and Pederson, 1999; Koval et al., 2000).

While there is more literature, and perhaps greater concern about youth smoking, stress and smoking have been examined for adults as well. For example, relapse to smoking and inability to stop smoking, have also been associated with stressful life events for adults (Wewers, 1988; Hymowitz et al., 1991; Mates \& Allison, 1992; McKee et al., 2003; Colby et al., 1994; Khwaja et al., 2006). Life events include, for example, divorce, death of a relative, financial problem, illness or injury or a move to a new residence. Most of these studies use retrospective data on stressful life events (Bonaguro and Bonaguro, 1987; McKee et al., 2003 e.g., Koval and Pederson, 1999; Koval et al., 2000; Bonaguro and Bonaguro, 1987, McKee et al., 2003).

Other studies have examined specific, stressful occupations such as nursing (Alexander et al., 1990) and medicine (Cooper et al., 1989). Studies with larger more generalizable populations tend to find that job stress and job control (together considered to be job strain) harm health and that one of the mechanisms may be poor habits such as smoking. For example, Hellerstedt and Jeffery (1997), using a sample of 3,843 workers in Minnesota, find that job demands increase smoking intensity for men as well as for women. However, Amick et al., (2002) use the Panel Study of Income Dynamics, a large and national representative survey, and find no significant effect of high-strain work (high psychosocial job demands and low job control) on all-cause mortality. Taken together, these studies suggest that job stress could be causally related to smoking.

There are at least two ways by which job-stress may be causally related to smoking. One, metioned above, is that stress presents physiological and psychological challenges to the body and that individuals respond by self-medicating through smoking to maintain homeostasis. Another mechanism is that stress can reduce self-control. While behavioral economists view 
'self-control' through the lens of discount rates, specifically hyperbolic functions (e.g., Gruber and Koszegi, 2001; Laibson, 1997, 2001), psychologists view self-control as a personality trait (e.g. time invariant) akin to will power (Sinha, 2001). Muraven and Baumeister (2000) find evidence that self control is a limited resource so that coping with stress (e.g, inhibiting negative emotions at work) reduces the amount of self control available for subsequent tasks (e.g controlling the urge to smoke). ${ }^{1}$ Most smokers indicate that they would like to quit smoking, ${ }^{2}$ but they lack the willpower to do so. Surprisingly, smokers tend to support higher tobacco taxes presumably as a method to help them quit as they lack self-control (Gruber and Mullainathan, 2002; Hersh, 2005; Kan, 2007).

This paper examines the effect of job-related stress on the smoking behavior of older workers. We use a self-reported measure of stress which is thought to capture the net impact of perception of, response to, and objective level of job related chronic or acute stress. We examine the extent to which job stress increases the likelihood that older working smokers relapse, continue to smoke and smoke more intensely. Using the Health and Retirement Survey (HRS), we examine workers and use separate samples of former and current smokers reflecting the different decisions that they face. The HRS offers several advantages, including a fairly large sample of older workers with data on smoking and job stress. The HRS also contains information on usually unobserved factors such as risk-taking preference, planning horizon and cognitive ability, that could potentially affect stress and smoking decisions. In addition, the HRS is a panel survey which allows us to account for unobserved individual specific factors in our estimation. We are also able to study quitting and relapse of older individuals over time.

\section{Data}

We use data from the 1992 to 2004 Health and Retirement Study (HRS). ${ }^{3}$ The HRS is a nationally representative longitudinal survey of individuals over 50 years and their spouses. The

\footnotetext{
${ }^{1}$ Muraven, Tice and Baumeister (1998) conduct a set of interesting experiments that find that individuals who had to exert self-control in one task perform worse (i.e. exhibit less self control) on a subsequent task that was unrelated to the first one.

${ }^{2}$ About $70 \%$ of current US adult smokers indicate that they would like to quit. Source: http://www.cdc.gov/tobacco/data_statistics/fact_sheets/cessation/quitting/index.htm

${ }^{3}$ Data from the 2006 HRS is also available. However, the occupation category codes used in 2006 were different from those in the previous years so that the original occupation codes were available only for persons who did not change jobs between waves. To maintain consistency and avoid any potential bias we did not use the 2006 data.
} 
HRS initially sampled persons in birth cohorts 1931 through 1941 and conducted follow up interviews biennially. We combined the original HRS data with the RAND HRS (version $\mathrm{H}$ ) data. The RAND HRS data is a subset of the HRS data containing cleaned versions of several variables. It was created by the RAND Center for the Study of Aging with the goal of making the data more accessible to researchers.

We restrict our sample to 10,775 individuals who were 50 to 64 years of age in 1992. In addition, we restrict our analyses to the 6,910 ever-smokers; almost no one starts to smoke after their early twenties. In our sample, only $0.28 \%(n=57)$ of those who reported never smoking in any wave initiate smoking in subsequent waves of the survey. Since our analysis focuses on the effects of job-related stress, we exclude observations for which the person reported not working at the time of the interview. We also exclude observations for which there are missing values on occupation codes, job stress or any of the demographic variables included in the analysis. This reduced our sample to 4,542 individuals. To exploit the panel nature of the HRS, we restrict the sample to individuals for whom at least two waves of data were available. Our final sample consists of 3,825 individuals and 17,043 person-year observations. In Table 1 we compare summary statistics in 1992 for the original HRS sample of 10,775 individuals and our final analysis sample of 3,825 individuals. Individuals in the analysis sample are more likely to be male and have slightly higher income levels than those in the HRS sample, but are very similar in terms of the other characteristics. This is to be expected since the analysis sample consists of only workers who are more likely to be male and would have higher income levels. As expected, the analysis sample has a much higher proportion of current and former smokers since never smokers are excluded from it.

We separately analyze the effect of stress for three groups - the full sample of ever smokers, a subsample of 'lagged smokers', and a subsample of 'lagged quitters'. Ever smokers have reported smoking sometime in the waves or otherwise self-report to smoking sometime in their life. Lagged smokers are defined to be persons who reported smoking at the previous interview wave and lagged quitters are defined as persons who reported having quit smoking by the previous interview wave. We delineate these groups because, due to the highly addictive nature of cigarettes, we expect that those who smoked last period and those who did not, will 
react differently to a change in stress. Individuals who have quit smoking may no longer be addicted to tobacco, and may not be as responsive to stress as those who are currently addicted to tobacco. Summary statistics for the subsamples of lagged smokers, ever smokers, lagged quitters and for the full sample of ever-smokers are shown in Table 2. The lagged smokers sample consists of 1,039 persons and the lagged quitters sample consists of 2,004 persons.

Owing to the fact that we focus on job stress, we restrict our sample to those who worked in the first wave. However, about $20 \%$ of this initial sample retires over subsequent waves of the survey, while approximately 3\% stops working. Current job stress is missing for these individuals. To examine the potential impact of attrition bias, we also analyze a larger sample that includes data from subsequent survey waves and adds controls for retirement and notworking status. Job stress and occupational codes are set to zero for persons who had retired or were not working. ${ }^{4}$

\section{Dependent Variables}

Our two dependent variables are: 1) a binary indicator for whether or not a person smokes at the time of the interview and 2) the number of cigarettes that a smoker usually smokes in a day. Data on smoking or not comes from a survey question: "Do you smoke cigarettes now?”. For those who report to be current smokers, they were asked the quantity of cigarettes smoked. This could be reported in number of cigarettes, packs or cartons. For individuals who reported the number of packs that they smoke in a day, we calculated the number of cigarettes by assuming that each pack contains 20 cigarettes. For individuals who reported the number of cartons smoked in a day, we assumed that each carton contains 10 packs or 200 cigarettes.

\section{Independent Variables}

Job Stress. The main independent variable for our study is a measure of job-related stress. In each wave of the HRS, respondents were asked how much they agree or disagree with the statement "My job involves a lot of stress". The answers were coded on a four-point scale, with 1 representing “strongly agree” and 4 representing "strongly disagree”. We created a binary

\footnotetext{
${ }^{4}$ We do not account for attrition bias due to mortality (4\%), survey non-response (8\%) or missing values (2\%).
} 
variable that took the value one if the individual reported that they strongly agree and zero otherwise. ${ }^{5}$

Most of the extant literature focuses on more objective measures of stress such as life events. However, psychologists often view stress as a process separating it into steps involving: perception, appraise, response and adaptation to harmful, threatening or challenging events (Lazarus and Folkman, 1984; Sinha, 2001). Thus individuals might perceive or interprete the same objective stressor (e.g. divorce) differently or could respond or adapt to it differently. One concern with using a self-reported measure is that it may be picking up objective stress, a point in the process (perception, appraisal, response, and adapt) or a combination of both. To the extent to which people respond to their own personalized view of the level of stress, self-reported stress is relevant variable for analyzing smoking decisions.

Table 3 reports means for stress levels and other factors by occupation. Occupations are listed in order of average level of stress in each occupation. Individuals in professional and technical support report the highest levels of stress, followed by managerial staff. Persons in farming, forestry or fishing report the lowest stress. This ranking of stress is almost the same as the ranking of occupation by educational attainment; the exception is that sales has a higher level of education than administration, but a slightly lower reported average stress. The most stressful occupations display the lowest smoking rates (farmers are slightly out of order with a lower smoking rate). ${ }^{6}$ These raw averages reveal a negative relationship between stress and smoking status.

To be able to exploit the panel nature of the HRS in our estimation, there must be sufficient within person variation in stress and smoking status. Of the 1,039 lagged smokers, about $29 \%$ change their report of job stress atleast once over the course of the study. The corresponding percentages for ever smokers and lagged quitters are $33 \%$ and $28 \%$ respectively. The variation in smoking status is slightly higher in the case of lagged smokers, with about $34 \%$

\footnotetext{
${ }^{5}$ In some preliminary specifications, we included indicators for 'strongly agree', 'agree' and 'disagree' with 'strongly disagree' being the omitted group. Since the results were very similar to those with the single binary variable we do not present them.

${ }^{6}$ The category of farmer is composed of different socio-economic types, ranging from farm owners to labors, which might explain the inconsistency.
} 
changing their status. However, a lower percentage of ever smokers (19\%) and only 6\% of lagged quitters change their smoking status over the study time period. In Table 4, we examine the transition probabilities for smoking status and job stress. About 9\% of lagged smokers transition from high job stress to low job stress from one period to the next, while 8\% transition from low stress to high stress. Of those who transitioned from high to low job stress, about 23\% changed jobs whereas about $15 \%$ of those who transitioned from low to high job stress changed jobs. The transition probabilities and percentage of job changers for ever smokers and lagged quitters are similar. In this older sample, more individuals are likely to quit smoking than relapse into it. About $13 \%$ of smokers quit smoking by the next time period whereas only $3 \%$ of former smokers start smoking again.

Demographics. We control for age, race, gender, marital status, household income and years of education. Household income is expressed in 10,000 1992 US dollars. For marital status, we create binary indicators for married, partnered and 'no spouse'. The 'no spouse' category combined persons who were separated, divorced, widowed or whose spouse was absent. The reference group is never married.

Occupation Categories. Occupational dummies help to control for occupation-related factors other than job stress that vary systematically and that could affect smoking. Examples would include workplace smoking bans, other working conditions, and workplace latitude. In addition, smoking rates, and thus smoking cues, may vary by occupation, affecting quitting and relapse. ${ }^{7}$ We classify individuals into eight occupation categories which were created from the 17 original categories reported in the HRS. The categories included: 1) managerial; 2) clerical and administrative support; 3) sales; 4) mechanical, construction and precision production; 5) service including private household, protective, food preparation, health and personal service; 6) operators, fabricators and laborers; and 7) farming, forestry and fishing. The reference category is professional and technical support and armed forces. We combine these two groups since there were only eight persons (15 person-years) in the armed forces. To test the robustness of our

\footnotetext{
${ }^{7}$ To some extent, occupation fixed effects may also adjust for the peer effects of workers smoking. While the smoking of worker-peers may be caused to some extent by common job stress, previous studies have found that being surrounded by others who smoke increases the likelihood of own smoking. For example, Fletcher (2009) finds that increasing the proportion of classmates who smoke by $10 \%$ increases the likelihood of individual smoking by 3 percentage points for a nationally representative sample of adolescents. Cutler and Glaeser (2007) find that individuals whose spouses smoke are $40 \%$ more likely to smoke.
} 
results we re-estimate the regression excluding these individuals. As expected, the results are almost identical to those with the full sample. We also re-estimate the regressions using the 17 original categories and combining professional and technical support and armed forces to form the reference group. The results are qualitatively similar and so are not presented here. ${ }^{8}$

Risk Attitudes. To measure risk preferences, the HRS asked respondents to choose among four different gambles. The first gamble was presented as follows:

"Suppose you are the only income earner in the family, and you have a good job. You are given the opportunity to take a new and equally good job, with a 50-50 chance that it will double your income and a 50-50 chance that it will reduce your income by a third. Would you take the new job?” If the answer was "no," the respondent was presented with the second gamble: "Suppose the chances were a 50-50 chance that it would double your income and a 50-50 chance that it would cut your income by 20 percent. Would you still take the new job?” If the answer to the first question was “yes", the interviewer asked: "Suppose the chances were a 50-50 chance that it would double your income and a 50-50 chance that it would cut your income by half. Would you still take the new job?”

Based on their choices, we classify respondents into four risk-aversion categories. The most risk-averse group consisted of persons who chose to stay with their current job. The next more risk-averse group consists of persons who chose the job with 50-50 chances of doubling their income or reducing by a fifth. The omitted group was the least risk-averse consisting of persons who chose to take a job with 50-50 chances of doubling their income or reducing it by half.

These questions were not asked in the 1994 and 1996 waves of the HRS and were also not asked if the interview was by proxy. From 1998 onwards, only some respondents were selected to answer these questions based on their cohort, age and/or random selection. ${ }^{9}$ Primarily because these questions are not asked in all waves, we create a dummy variable indicating missing. For robustness, we also use a carry-forward approach and replaced the missing information with data from the previous wave or with the mean if more than one wave of data

\footnotetext{
${ }^{8}$ Both sets of results are available upon request.

${ }^{9}$ For details see: http://www.rand.org/labor/aging/dataprod/randhrsh.pdf
} 
was available. The results are nearly identical across the two approaches. In the reported results we use the missing dummy variable approach.

Financial Planning Horizon. To measure planning behavior, the HRS asked respondents: "In deciding how much of their (family) income to spend or save, people are likely to think about different financial planning periods. In planning your (family's) savings and spending, which of the time periods listed in the booklet is most important to you [and your (husband/wife/partner)]?” We create separate binary variables for each of the answers: "next few months", "next year", "next few years", "next 5-10 years" and "longer than 10 years". The shortest horizon "next few month" served as the reference group. These questions were also not asked in the 1994 and 1996 waves or if the interview was by proxy. In 1998 and 2000 respondents were selected to answer this question based on a combination of their cohort and random selection. In 2002, individuals who were 65 years and older were not asked this question. The missing values are treated in the same manner as above in the discussion of risk-aversion. .

Cognition. The HRS included a set of questions measuring the cognitive status of respondents. We constructed a cognitive score that was the sum of three separate measures: immediate word recall, delayed word recall and series seven. The total score varied from 0 to 25 with a higher score representing a higher cognitive ability. The immediate word recall measure counted the number of words that the individual could recall immediately after a list of 10 words was read to them by the interviewer. The delayed word recall measure counted the number of words from the same list that the individual could recall after five minutes. For the series seven measure individuals were asked to serially subtract seven starting from 100 . The measure was the number of correct answers. The series seven question was not asked in 1992 and 1994 and none of these questions were asked to proxy respondents. We constructed the cognition score for 1996 through 2004 and treated the missing observations similar to risk aversion and financial planning horizon.

Labor Force Status. To check for the presence of attrition bias, we analyze the labor force status of our sample over the survey waves. We create a dummy variable for whether or not a person was retired. We also create a variable (not working) that took the value of one if the 
person reported being unemployed, not working due to disability or not in the labor force, and zero otherwise. We also create a binary variable for part-time work status of the individual.

\section{Methods}

We employ several empirical methods to analyze the effect of job related stress on smoking decisions. As a first step, we use ordinary least squares (OLS) to study the association between stress and smoking. The OLS regression also control for demographics, occupation fixed effects and year fixed effects. The latter is important due to the secular decline in smoking as well as the decline with age. Since persons might select their occupation (and hence job stress) based on unobservable characteristics that also affect smoking, the OLS estimates cannot be interpreted as causal.

$$
S_{i t}=\alpha+\beta \text { Stress }_{i t}+\gamma X_{i t}+O C_{i t}+T_{t}+\varepsilon_{i t}
$$

Where, $S_{i t}$ represents individual i's smoking status in period $t$; Stress ${ }_{i t}$ represents the individual's job related stress in period $t ; X_{i t}$ represents a vector of observable factors that may affect the smoking decision; $O C_{i t}$ is an occupation fixed effect; $T_{t}$ represents year fixed effects; and $\varepsilon_{i t}$ represents an idiosyncratic error term.

Equation (1) estimates the effect of stress on smoking conditional on observable characteristics and unobserved occupation and time effects. However, there might be other unobserved individual specific factors such as preferences that affect both smoking decisions and job stress. To account for the presence of such factors, we estimate the following equation:

$$
S_{i t}=\alpha+\beta \text { Stress }_{i t}+\gamma X_{i t}+O C_{i t}+T_{t}+\eta_{i}+\varepsilon_{i t}
$$

Where $\eta_{i}$ represents an unobserved individual specific term that affects the decision to smoke. Equation 2 allows $\eta_{i}$ to be correlated with Stress $_{i t}$, so that certain individuals might systematically be more likely to be in jobs with (say) a high stress level and be more likely to smoke. 
While the individual fixed effects model accounts for the endogeneity of job stress due to time-invariant person-specific factors, $\beta$ might not represent the causal effect of stress on smoking because of two additional sources of potential endogeneity. The first is the presence of time-varying unobservables that are correlated with both stress and smoking. Examples of such factors would be marital problems, death of a close relative, or a change in mental or physical health. In our empirical analysis, we conduct robustness checks to see if our estimate of $\beta$ is sensitive to the inclusion of certain time-varying factors that are observable to us. However, the estimation method does not rule out other unobserved variables. The second source of potential endogeneity is reverse causation. Smoking may alleviate stress (Aronson et al., 2008; Kassel, Stroud and Paronis, 2003) or smokers who are unable to quit may report higher stress to justify their decision to continue smoking.

\section{Results}

Table 5 reports the OLS and fixed effects regression results for lagged smokers. High job stress is positively and significantly associated with being a smoker. Accounting for the timeinvariant, person-specific characteristics through individual FE increases the magnitude and significance of the coefficient indicating that the OLS estimates are biased downwards. One explanation is that individuals who are less likely to smoke might also be more likely to select a high stress job. There are several potential person-specific time-invariant omitted variables that could explain the negative bias of OLS. Unmeasured differences in family background, quality of education, cognitive function, level of self-control, ability to handle stress, long planning horizon, discount rate, mental health problems ${ }^{10}$ or anxious personality could all result in this bias. Higher levels in all but the last three in this list would likely lead to a willingness to accept the greater stress associated with a challenging occupation and would also tend to result in lower smoking rates. From these results, we have to be agnostic as to which factor or set of factors account for the bias in the OLS results. We can only determine the direction of the bias. However, below we test whether specific factors that we can measure could account for the bias.

\footnotetext{
10 There are high rates of smoking in schizophrenia and mental health problems in general. There is evidence that those with schizophrenia smoke to alleviate attention deficits. Smoking may help to address cognitive deficits in those with schizophrenia or other mental health problems. See for instance Sacco et al. 2005.
} 
Job stress also has a larger coefficient in FE regressions as compared to OLS in estimates of the number of cigarettes smoked. However, the difference in magnitude and significance is slight. It is reasonable that most of the bias due to the person-specific time-invariant omitted variables occurs largely through the decision to smoke, not the number of cigarettes smoked conditional on being a current smoker. For these older individuals, the decision to smoke is really a decision to quit or not. Quitting would be the pivotal event. Cigarettes are very addictive and long-term smokers have difficulties quitting even when they want to quit. Thus personspecific time-invariant factors would likely be most influential in the decision to quit, and less so regarding the number of cigarettes smoked. ${ }^{11}$

Table 6 presents the estimated coefficient on stress from three sets of regressions; each set is composed of results for OLS and FE. The first set of regressions examines the effect of stress on smoking status for the full sample of ever-smokers. The second set examines the number of cigarettes smoked by ever-smokers who currently smoke. ${ }^{12}$ The third set of regressions analyzes the smoking status of lagged quitters (ever-smokers who did not smoke last year). We only display the coefficient on stress in each regression as stress is the key variable of interest; the coefficients on the control variables are qualitatively similar to those in Table 5.

Job stress positively affects the smoking status and the intensity of smoking for eversmokers in OLS regressions. Accounting for the some of the endogeneity of stress by controlling for time-invariant personal characteristics (FE regressions), reduces the magnitude of the estimated coefficient for this group. These results suggest that the source of the endogeneity bias for the ever-smokers is different from that for the lagged smokers. This could occur for several reasons. Recall that the current smokers in this set do not overlap completely with the smokers in lagged smokers (see footnote 8). The sample of ever smokers also includes former smokers. As can be seen in Table 2, 68\% of the ever-smokers have already quit. This sample would have been

\footnotetext{
${ }^{11}$ Self-control levels likely vary systematically across individuals but also there will be perturbations to the systematic level. So some variation will be picked up in individual FE.

${ }^{12}$ Note that the set of current smokers from the sample of ever-smokers overlaps with but is not identical to current smokers from the set of lagged smokers. This is because lagged smokers have to be the data set for at least two waves (data from the previous wave is needed to establish lagged smoking status), while ever-smokers do not as the information on ever-smoking comes from retrospective questions.
} 
between 22 and 36 years of age when the first surgeon general's report on smoking as an important health hazard came out in 1964. Many of these smokers probably started smoking when they were teenagers, which would have been prior to the barrage of information on the health hazards of smoking. When they became aware of the harms of smoking they might have responded by quitting. Those who quit in response are likely to be systematically different from those who continued smoking into their 50s and 60s. This systematic difference could account for the differential effect of omitted variables on stress and smoking.

Also seen in Table 6 is that lagged quitters do not significantly change their smoking behavior in response to stress. This may be in part due to the small percentage of this sample that starts to smoke (only 2\% as seen in Table 4). Lack of power may account for the lack of significance. Overall, these results suggest that the group most vulnerable to job stress is lagged smokers. These individuals are less likely to quit smoking if they are under stress and also smoke more in response to stress.

Next, we examine whether risk attitudes, planning horizon or cognition explain the observed association between job stress and smoking. While there are other factors that we believe may be important unobserved covariates, these are relevant factors that are available in HRS. However, because these variables are only available for a subset of individuals, we do not include them in our primary specification. ${ }^{13}$ These additional regressions are displayed in Table 7. The first column of Table 7 presents the baseline OLS regression and the following columns display results that include each of these factors one by one in the regression specification. Since there were several missing values for each of these variables and because we want to be able to compare across regressions with the same sample, we include missing dummies when applicable. The variables for risk aversion, planning horizon and cognition were set to zero if they were missing. The coefficient on job stress does not change with the inclusion of these additional variables suggesting that risk attitudes, time preferences or cognition scores are not the key component of the omitted variable bias in the OLS estimates. In fact, only financial planning has

\footnotetext{
${ }^{13}$ Risk aversion was missing for $92 \%$ of the sample, financial planning horizon for $85 \%$ of the sample and cognition for $34 \%$ of the sample.
} 
a significant impact on smoking status; as expected, a longer time horizon reduces the probability of smoking.

In Table 8 we examine the bias introduced by sample attrition related to labor force status. We include dummy variables for whether or not a person was retired, otherwise not working, or working part time with full time employment as the reference category. The results show that for the sample of lagged smokers, individuals who retire or stop working are significantly less likely to continue smoking. However, the number of cigarettes smoked does not vary significantly among those who continue to smoke. Accounting for attrition due to retirement or non-working status has little impact on the estimated coefficient on job stress, suggesting that our results are robust to sample attrition. Attrition bias might still be a concern if, for example, individuals who have retired are less able to cope with stress relative to those who have not retired. Including a binary indicator for the part time nature of the job does not affect smoking or the effect of stress on smoking.

While the FE regressions control for time-invariant omitted variables, they do not account for omitted variables that vary over time. In Table 9 we present the results from some robustness checks. We examine the impact of time varying factors such as physical and mental (depression) health, job tenure, work atmosphere and death of a parent. Including these variables in the fixed effects regression does not change the effect of stress on smoking status for lagged smokers. We also examine the impact of job stress for males and females separately. Males appear to react more strongly to stress with an estimated coefficient of 0.0681 (significant at 5\% level) as compared to females who had an estimated coefficient of 0.0495 (significant at 10\% level).

\section{Discussion}

Examining older workers, we find that job stress is positively related to smoking and to the number of cigarettes smoked by current smokers. In our estimates for lagged smokers, we find that compared to OLS regressions, individual FE regressions display coefficients on stress that are larger in magnitude and significance. Because all time-invariant factors are essentially controlled for in the individual FE regressions, the OLS bias seems to occur due to time-invariant 
personal characteristics that were omitted from the initial regressions. These factors must not operate as importantly in regressions of the number of cigarettes conditional on smoking because the OLS bias for these results is considerably smaller than it is for smoking status.

While we hypothesize that the above and other potential factors could account for the bias, we are constrained in what we can measure. In robustness checks, we find that the set of planning horizon variables is a significant factor of the expected sign (long-term planning reduces smoking), but inclusion of this set does not affect the coefficient on high stress. Our measures of cognition and risk-aversion are not significant explanatory variables. We also find that our results are robust to attrition due to retirement or not-working status and to the inclusion of certain time varying factors such as mental and physical health, job tenure and death of a parent.

Our study advances the literature in several ways. First, we focus on older workers and job stress. Older workers are those most at risk for smoking-related morbidity and mortality. Quitting, even at later ages, improves health and functioning and can prevent some of the adverse consequences. Second, we explicitly address the fact that older individuals are not going to newly initiate smoking but will have different decisions to make based on whether they are recent former smokers, recent quitters or current smokers. Third, we compare results from OLS and individual fixed effects to assess the impact of omitted time-invariant factors. Fourth, because the FE approach does not address potential time varying factors that could bias our results, we examine various time varying measures of physical and mental health, external life stress, and job tenure. We note, however, that our efforts do not preclude the existence of other time-varying factors that are correlated with both job stress and the propensity to smoke. Fifth, we use occupational fixed effects to control for occupational specific characteristics other than stress. Sixth, we examine the potential impact of attrition bias; however, we are unable to account for selection into the sample based on working status because we cannot identify factors that would influence the decision to work, but not the decision to smoke. Lastly, while most of the extant literature examines life-events to measure stress, we examine job stress. 
The self-reported measure of stress that we use has strengths and weaknesses. To the extent that people respond to their own personalized view of their level of stress and not only the objective measure, self reported stress is a relevant variable for analyzing smoking decisions. However, individuals might have different definitions of what constitutes “a lot of stress" and could also vary in their response to a stressful event. The response to stress could be negative such as anxiety, fatigue, depression, and other physiological and psychological reactions. The alternative of using an external measure of stress would introduce new and different problems. The respondent may not even perceive the objectively measured stress to be aversive, that is, what is stressful for the average person, is not necessarily stressful for the specific respondent. The measure that we use is more akin to the personalized recognition of an aversive situation; we think that this is an appropriate measure for our purposes.

Are smokers irrational or rational with regarding to tobacco? Smoking may be irrational in the sense of low willpower, or hyperbolic discounting (Laibson 1997, 2001). There is evidence that most smokers want to quit but cannot. Further, smokers tend to support higher tobacco taxes presumably as a method to help them quit because they lack self-control (Gruber and Mullainathan, 2002; Hersh, 2005). Smokers are addicted; they may not have the willpower to quit even though they say that they want to quit; stress may exacerbate the problem. Studies in behavioral economics are increasingly positing that public policies to address harmful consumption in situations or systematically low willpower can be welfare enhancing (Thaler and Sunstein, 2003; O’Donoghue and Rabin, 2003; Camerer, et al., 2003, Bernheim and Rangel, 2006).

On the other hand, smoking may be 'rational' in terms of self medication of stress, obtaining compensating wage differentionals for accepting stress or enjoyment of smoking. However, there may be better alternatives to coping with stress than smoking. For example, it may be 'rational' for schizophrenics to smoke to treat attention deficit problems (Sacco et al., 2005). However, they might be better off medicating and handling their stress in other ways; the nicotine patch, for example, provides nicotine without the smoke harming one's self and others. Another approach could be to teach methods to bolster self-control, as psychologists are making strides in teaching self-control (Muraven et al., 1999; Muraven and Baumeister, 2000; Mischel 
and Mischel, 1983; Mischel et al., 1996). This could have positive spillovers to productivity as well.

The results of this paper suggest that high stress workers, cet. par., may be high at risk for continued and increased use of tobacco. It might be productive and profitable for firms, for example, to offer programs that help workers cope with stress as well as quit smoking and prevent former smokers from relapsing. Firms could also ameliorate some of the job stress, cover cessation services and products in insurance, and/or ban smoking at work. Smokers might be able to find ways of coping with stress that do not compromise their health so greatly. 


\section{References:}

Amick BC, 3rd, McDonough P, Chang H, Rogers WH, Pieper CF, Duncan G. (2002). Relationship between all-cause mortality and cumulative working life course psychosocial and physical exposures in the United States labor market from 1968 to 1992. Psychosom Med 64(3): 370-81.

Aronson KR, Almeida DM, Stawski RS, Klein LC and Kozlowski LT. (2008). Smoking is associated with worse mood on stressful days: Results from a national dairy study. Annals of Behavioral Medicine 36: 259-269

Baumeister R and Vohs K. (2003). Willpower, choice, and self-control. In: Loewenstein G, Read D and Baumeister R (eds.) Time and Decision. New York: Russell Sage Foundation, pp: 201216.

Baumeister RF, Bratslavsky E, Muraven M, and Tice D. (1998). Ego depletion: Is the active self a limited resource? Journal of Personality and Social Psychology 74(5): 1252-65.

Benabou R and Tirole J. (2004). Willpower and personal rules. Journal of Political Economy 112(4): 848-87.

Benhabib J and Bisin A. (2005). Modeling internal commitment mechanisms and self-control: A neuroeconomics approach to consumption-saving decisions. Games and Economic Behavior 52(2): 460-492.

Bernheim BD and Rangel A (2005). From neuroscience to public policy: A new economic view of addiction. Swedish Economic Policy Review 12.

Bhattacharya J and Lakdawalla D. (2004). Time-inconsistency and welfare. NBER working paper No. W10345, March 2004.

Available at SSRN: http://ssm.com/abstract=515239.

Bonaguro JA and Bonaguro EW. (1987). Self-concept, stress symptomatology, and tobacco use. Journal of School Health 57(2):56-58.

Brandon TH. (1994). Negative affect as motivation to smoke. Current Directions in Psychological Science 3(2): 33-37.

Camerer C, Issacharoff S, Loewenstein G, O'Donoghue T, Rabin M. (2003). Regulation for conservatives: behavioral economics and the case for "asymmetric paternalism". University of Pennsylvania Law Review 151(3): 1211-1254.

Chaloupka FJ. (1991). Rational addictive behavior and cigarette smoking. J Political Economy 99(4): 722-742. 
Chaloupka FJ and Warner KE. (2000). The economics of smoking. In: Culyer AJ and Newhouse JP (eds.) Handbook of Health Economics. Vol. 1B, pp. 1539-1627. Elsevier: North-Holland.

Colby JP Jr, Linsky AS and Straus MA. (1994). Social stress and state-to-state differences in smoking and smoking related mortality in the United States. Social Science Medicine 38(2): 373-381.

Cooper CL, Rout U, Faragher B. (1989). Mental health, job satisfaction, and job stress among general practitioners. British Medical Journal 298(6670): 366-70.

Cutler D and Glaeser E. (2007). Social interactions and smoking. Harvard Institute of Economic Research Discussion Paper No. 2153.

Douglas SM. (1998). The duration of the smoking habit. Economic Inquiry 36(1): 49-64.

Fletcher J. (2009). Social interactions and smoking: Evidence using multiple student cohorts, instrumental variables, and school fixed effects. Health Economics (forthcoming).

Forster $\mathrm{M}$ and Jones AM. (2001). The role of tobacco taxes in starting and quitting smoking: Duration analysis of British data. Journal of the Royal Statistical Society (Series A) 164:517547.

Frederick S, Loewenstein G, O'Donoghue T. (2002). Time discounting and time preference: A critical review. Journal of Economic Literature 40(2): 350-401.

Geoders NE and Guerin GF. (1994). Non-contingent electric footshock facilitates the acquisition of intravenous cocaine self-administration in rats. Psychopharmacology 21: 13-33.

Gruber J and Koszegi B. (2004). Tax incidence when individuals are time inconsistent: The case of cigarette excise taxes. Journal of Public Economics 88(9-10): 1959-1988.

Gruber J and Koszegi B. (2001). Is addiction 'rational'? Theory and evidence. Quarterly Journal of Economics 116(4):1261-1303.

Gruber J and Mullainathan S. (2002). Do cigarette taxes make smokers happier? NBER Working Paper No. W887.

Gul F and Pesendorfer W. (2001). Temptation and self-control. Econometrica 69(6): 1403-35.

Gul F and Pesendorfer W. (2007). Harmful addiction. Review of Economic Studies 74(1): 147172.

Hellerstedt WL and Jeffery RW. (1997). The association of job strain and health behaviours in men and women. International Journal of Epidemiology 26(3): 575-83. 
Hersch J. (2005). Smoking restrictions as a self-control mechanism. Journal of Risk and Uncertainty 31(1): 5-21.

Hymowitz N, Sexton M, Ockene J and Grandits G. (1991). Baseline factors associated with smoking cessation and relapse. Preventive Medicine 20(5): 590-601.

Kan K. (2007). Cigarette smoking and self-control. Journal of Health Economics 26(1): 61-81.

Kassel JD, Stroud LR and Paronis CA. (2003). Smoking, stress, and negative affect: Correlation, causation and context across stages of smoking. Psychological Bulletin 129(2): 270-304.

Khwaja A, Sloan F and Chung S. (2006). Learning about individual risk and the decision to smoke. International Journal of Industrial Organization 24(4): 683-699.

Kim K. (2003). Peers and adolescent smoking. Review article for Addiction 98(S1): 37-55.

Koob GF and Le Moal M (1997). Drug abuse: Hedonic homeostatic dysregulation. Science 278: 52-58.

Koval JJ, Pederson LL, Mills CA, McGrady GA and Carvajal SC. (2000). Models of the relationship of stress, depression, and other psychosocial factors to smoking behavior: A comparison of a cohort of students in grades 6 and 8. Preventive Medicine 30(6): 463-477.

Laibson D. (2001). A cue-theory of consumption. Quarterly Journal of Economics 116(1): 81119.

Laibson D. (1997). Golden eggs and hyperbolic discounting. Quarterly Journal of Economics 112(2): 443-77.

Lasser K, Boyd JW, Woolhandler S, Himmelstein DU, McCormick D, Bor DH. (2000). Smoking and mental illness: A population-based prevalence study. Journal of the American Medical Association 284(20): 2606-2610.

Lazarus RS and Folkman S (1984). Stress, Appraisal and Coping. New York: Springer.

Llena-Nozal A, Lindeboom M and Portrait F. (2004). The effect of work on mental health: Does occupation matter? Health Economics 13(10): 1045-1062.

Loewenstein G. (2000). Willpower: A decision-theorist's perspective. Law and Philosophy 19(1): 51-76.

Marlatt GA and Gordon J. (1985). Relapse Prevention. New York: Guilford Press.

Mates D and Allison KR. (1992). Sources of stress and coping responses of high school students. Adolescence 27(106): 461-474. 
McEwen BS. (2000). Allostasis and allostatic load: Implications for neuropsychopharmacology. Neuropsychopharmacology 22 (2): 108-24.

McKee S. Developing human labortory models of smoking lapse behavior for medical screening . Addiction Biology, forthcoming.

Mischel H and Mischel W. (1983). The development of children's knowledge of self-control strategies. Child Development 54(3): 603-619.

Mischel W, Cantor N and Feldman S. (1996). Principles of self-regulation: the nature of willpower and self-control. In: Higgins ET \& AW Kruglanski (eds.), Social Psychology: Handbook of Basic Principles. New York: Guilford Press, pp. 329-360.

Muraven M and Baumeister RF. (2000). Self-regulation and depletion of limited resources: Does self-control resemble a muscle? Psychological Bulletin 126(2): 247-259.

Muraven M, Baumeister RF, Tice DM. (1999. Longitudinal improvement of self-regulation through practice: Building self-control strength through repeated exercise. Journal of Social Psychology 139(4): 446-457.

Muraven M, Tice DM, Baumeister RF. (1998). Self-control as a limited resource: Regulatory depletion patterns. Journal of Personality and Social Psychology 74(3): 774-789.

Niaura R, Shadel WG, Britt DM and Abrams DB. (2002). Response to social stress, urge to smoke, and smoking cessation. Addictive Behaviors 27(2): 241-250.

O’Donoghue T and Rabin M. (2003). Studying optimal paternalism, illustrated with a model of Sin Taxes. AER papers and proceedings, 93(2): 191.

Rubinstein A. (2003). Economics and psychology? The case of hyperbolic discounting. International Economic Review 44(4): 1207-1216.

Sacco KA, Termine A, Seyal AA, Dudas MM, Vessicchio JC, Krishnan-Sarin S, Jatlow PI, Wexler BE, George TP (2005). Effects of cigarette smoking on spatial working memory and attentional deficits in schizophrenia: Involvement of nicotinic receptor mechanisms. Archives of General Psychiatry 62: 649-659

Selye H. (1976). The Stress of Life. New York: McGraw Hill.

Seeman TE, Singer BH, Rowe JW, Horwitz RI, adn McEwan BS (1997). Price of adoptationallostatic looad and its health consequences. Macarthur studies of successful aging. Archives of Internal Medicine 157(19): 2259-2268.

Sinha R. (2001). How does stress increase risk of drug abuse and relapse? Psychopharacology 158: 343-359. 
Shiffman S, Balabanis MH, Paty JA, Engberg J, Gwaltney CJ, Liu KS, Gnys M, Hickcox M and Paton SM. (2000). Dynamic effects of self-efficacy on smoking lapse and relapse. Health Psychology 19(4): 315-323.

Sloan FA, Osterman J, Picone G, Conover C and Taylor DH. (2004). The Price of Smoking. Cambridge, Massachusetts: The MIT Press.

Sterling P and Eyer J. (1988). Allostasis: A new paradigm to explain arousal pathology. In: Fisher S and J. Reason (eds.), Handbook of Life Stress, Cognition and Health. New York: John Wiley \& Sons.

Taylor DH, Hasselblad V, Henley SJ, Thun MJ and Sloan FA. (2002). Benefits of smoking cessation for longevity. American Journal of Public Health 92(6): 990-996

Thaler R and Shefrin HM. (1988). An economic theory of self-control. Journal of Political Economy 89(2): 392-406.

Thaler R and Sunstein CR. (2003). Libertarian paternalism. AER Papers and Proceedings 93(02): 175-79.

US Department of Health and Human Services. (2000). Reducing Tobacco Use: A Report of the Surgeon General. Atlanta: U.S. Department of .Health and Human Services, Public Health Service, Centers Disease Control and Prevention, National Center for Chronic Disease Prevention and Health Promotion, Office on Smoking and Health.

US Department of Health and Human Services. (2004). The Health Consequences of Smoking: A Report of the Surgeon General. Atlanta, GA: U.S. Department of Health and Human Services, Centers for Disease Control and Prevention, National Center for Chronic Disease Prevention and Health Promotion, Office on Smoking and Health.

Weaver GD, Turner NH, and O'Dell KJ. (2000). Depressive symptoms, stress, and coping among women recovering from addiction. Journal of Substance Abuse Treatment 18(2): 161167.

Wewers ME. (1988). The role of postcessation factors in tobacco abstinence: Stressful events and coping responses. Addictive Behaviors 13(3):297-302.

Wills TA and Shiffman S. (1985). Coping behavior and its relationship to substance abuse: a conceptual framework. In: Shiffman S \& Wills TA, (eds.). Coping and Substance Use. New York: Academic Press, pp. 3-24. 
Table 1: Summary statistics in 1992 for HRS sample and analysis sample

\begin{tabular}{l|llll}
\hline & \multicolumn{2}{|c}{ HRS Sample } & \multicolumn{2}{c}{ Analysis Sample } \\
& Mean & Std. Dev & Mean & Std. Dev. \\
\hline Former smoker & 0.37 & & 0.60 & \\
Current smoker & 0.27 & & 0.40 & \\
High stress & 0.19 & & 0.19 & \\
Age & 55.86 & $(3.64)$ & 55.23 & $(3.44)$ \\
Black & 0.17 & & 0.15 & \\
Other race & 0.04 & & 0.03 & \\
Male & 0.49 & & 0.62 & \\
Married & 0.75 & & 0.76 & \\
Household income & 4.66 & $(5.07)$ & 5.28 & $(4.84)$ \\
('0,000 1992 USD) & & & & \\
Years of education & 12.02 & $(3.24)$ & 12.45 & $(2.97)$ \\
Professional & 0.16 & & 0.14 & \\
Managerial & 0.15 & & 0.15 & \\
Administrative & 0.15 & & 0.14 & \\
Sales & 0.10 & & 0.10 & \\
Mechanical & 0.11 & & 0.13 & \\
Service & 0.15 & & 0.15 & \\
Operator & 0.15 & & 0.17 & \\
Farm & 0.03 & & 0.03 & \\
\hline N (persons) & 10,775 & 3,825 & \\
\hline
\end{tabular}

Note: The number of observations for high stress and occupation in the HRS sample are less than 10,775 due to missing values. 
Table 2: Summary statistics

\begin{tabular}{l|llllll}
\hline & \multicolumn{2}{|l}{ Lagged smokers $^{\text {a }}$} & \multicolumn{2}{l}{ Ever-smokers $^{\text {a }}$} & \multicolumn{3}{l}{ Lagged quitters $^{\text {a }}$} \\
& Mean & Std. Dev & Mean & Std. Dev. & Mean & Std. Dev. \\
\hline Former smoker & 0.12 & & 0.68 & & 0.98 & \\
Current smoker & 0.88 & & 0.32 & & 0.02 & \\
High stress & 0.17 & & 0.16 & & 0.14 & \\
Age & 59.70 & $(4.24)$ & 59.26 & $(4.78)$ & 60.92 & $(4.56)$ \\
Black & 0.15 & & 0.14 & & 0.13 & \\
Other race & 0.03 & & 0.03 & & 0.03 & \\
Male & 0.55 & & 0.62 & & 0.66 & \\
Married & 0.65 & & 0.74 & & 0.78 & \\
Household income & 5.01 & $(6.40)$ & 5.78 & $(6.72)$ & 6.50 & $(7.26)$ \\
('0,000 1992 USD) & & & & & & \\
Years of education & 12.21 & $(2.61)$ & 12.63 & $(2.91)$ & 13.01 & $(2.91)$ \\
Professional & 0.10 & & 0.14 & & 0.17 & \\
Managerial & 0.13 & & 0.15 & & 0.16 & \\
Administrative & 0.15 & & 0.14 & & 0.13 & \\
Sales & 0.10 & & 0.11 & & 0.11 & \\
Mechanical & 0.12 & & 0.12 & & 0.11 & \\
Service & 0.19 & 0.15 & & 0.13 & \\
Operator & 0.19 & 0.16 & & 0.15 & \\
Farm & 0.03 & 0.03 & & 0.04 & \\
\hline Obs. (person-year) & 3,618 & 17,043 & & 7,951 & \\
N (persons) & 1,039 & 3,825 & & 2,004 & \\
\hline
\end{tabular}

${ }^{a}$ Lagged smokers are defined to be persons who reported smoking at the previous interview wave and lagged quitters are defined as persons who reported having quit smoking by the previous interview wave. Ever smokers are those who have reported smoking sometime in their life. 
Table 3: Means by occupation for ever-smokers*

\begin{tabular}{l|lllllllr}
\hline & Stress & \multicolumn{2}{l}{ Yrs of education } & \multicolumn{2}{l}{ Household income } & Male & Smoker & Obs. \\
\hline Professional & 0.23 & 15.42 & $(1.96)$ & 8.30 & $(8.28)$ & 0.56 & 0.21 & 2,447 \\
Managerial & 0.22 & 14.04 & $(2.38)$ & 8.96 & $(9.62)$ & 0.72 & 0.27 & 2,552 \\
Administrative & 0.17 & 12.87 & $(1.77)$ & 5.34 & $(6.93)$ & 0.25 & 0.36 & 2,309 \\
Sales & 0.15 & 13.12 & $(2.37)$ & 6.21 & $(7.21)$ & 0.62 & 0.31 & 1,811 \\
Mechanical & 0.12 & 11.52 & $(2.48)$ & 4.72 & $(3.74)$ & 0.95 & 0.33 & 1,979 \\
Service & 0.13 & 11.44 & $(2.49)$ & 3.38 & $(3.22)$ & 0.39 & 0.40 & 2,592 \\
Operator & 0.12 & 10.82 & $(2.81)$ & 4.05 & $(2.77)$ & 0.81 & 0.39 & 2,782 \\
Farm & 0.08 & 9.82 & $(3.78)$ & 4.32 & $(5.15)$ & 0.95 & 0.28 & 571 \\
\hline
\end{tabular}

* Standard deviations for non-binary variables are reported in parentheses. 
Table 4: Transition probabilities for smoking status and stress

\begin{tabular}{|c|c|c|c|c|c|}
\hline \multicolumn{6}{|c|}{ Lagged Smokers $^{\text {a }}$} \\
\hline & & \multicolumn{2}{|c|}{ Smoking status } & \multicolumn{2}{|c|}{ High stress } \\
\hline & & 0 & 1 & 0 & 1 \\
\hline \multirow{2}{*}{ Smoking status } & 0 & 1.28 & 2.71 & & \\
\hline & 1 & 12.72 & 83.29 & & \\
\hline \multirow{2}{*}{ High stress } & 0 & & & 74.45 & 8.26 \\
\hline & 1 & & & 9.31 & 7.99 \\
\hline \multicolumn{6}{|l|}{ Ever Smokers $^{a}$} \\
\hline & & \multicolumn{2}{|c|}{ Smoking status } & \multicolumn{2}{|c|}{ High stress } \\
\hline & & 0 & 1 & 0 & 1 \\
\hline \multirow{2}{*}{ Smoking status } & 0 & 64.50 & 2.42 & & \\
\hline & 1 & 5.33 & 27.75 & & \\
\hline \multirow{2}{*}{ High stress } & 0 & & & 75.74 & 7.53 \\
\hline & 1 & & & 8.99 & 7.75 \\
\hline \multicolumn{6}{|l|}{ Lagged Quitters $^{\text {a }}$} \\
\hline & & \multicolumn{2}{|c|}{ Smoking status } & \multicolumn{2}{|c|}{ High stress } \\
\hline & & 0 & 1 & 0 & 1 \\
\hline \multirow{2}{*}{ Smoking status } & 0 & 97.48 & 1.38 & & \\
\hline & 1 & 0.87 & 0.27 & & \\
\hline \multirow{2}{*}{ High stress } & 0 & & & 78.36 & 6.76 \\
\hline & 1 & & & 8.24 & 6.64 \\
\hline
\end{tabular}

${ }^{a}$ Lagged smokers are defined to be persons who reported smoking at the previous interview wave and lagged quitters are defined as persons who reported having quit smoking by the previous interview wave. Ever smokers are those who have reported smoking sometime in their life. 
Table 5: Effect of job stress on smoking among lagged smokers ${ }^{\mathrm{a}}$

\begin{tabular}{|c|c|c|c|c|}
\hline & $\begin{array}{l}\text { Smoking status } \\
\text { OLS }\end{array}$ & $\begin{array}{l}\text { Smoking } \\
\text { status } \\
\text { FE }\end{array}$ & $\begin{array}{l}\text { \# of cigarettes } \\
\text { OLS }\end{array}$ & $\begin{array}{l}\text { \# of cigarettes } \\
\text { FE }\end{array}$ \\
\hline High stress & $\begin{array}{l}0.0262 * \\
(0.0135)\end{array}$ & $\begin{array}{l}0.0598 * * * \\
(0.0194)\end{array}$ & $\begin{array}{l}1.741^{* * *} \\
(0.621)\end{array}$ & $\begin{array}{l}1.967^{* * *} \\
(0.590)\end{array}$ \\
\hline Age & $\begin{array}{l}0.0218 \\
(0.0302)\end{array}$ & $\begin{array}{l}0.0505 \\
(0.0406)\end{array}$ & $\begin{array}{l}-0.208 \\
(1.205)\end{array}$ & $\begin{array}{l}-1.581 \\
(1.229)\end{array}$ \\
\hline Age squared & $\begin{array}{l}-0.000196 \\
(0.000253)\end{array}$ & $\begin{array}{l}-0.000370 \\
(0.000296)\end{array}$ & $\begin{array}{l}-0.000826 \\
(0.00992)\end{array}$ & $\begin{array}{l}0.0148^{*} \\
(0.00899)\end{array}$ \\
\hline Black & $\begin{array}{l}-0.0270 * \\
(0.0162)\end{array}$ & $\begin{array}{l}- \\
-\end{array}$ & $\begin{array}{l}-6.695^{* * * *} \\
(0.494)\end{array}$ & $\begin{array}{l}- \\
-\end{array}$ \\
\hline Other race & $\begin{array}{l}-0.0456 \\
(0.0334)\end{array}$ & - & $\begin{array}{l}-7.256^{* * *} \\
(1.069)\end{array}$ & - \\
\hline Male & $\begin{array}{l}-0.0232 * \\
(0.0130)\end{array}$ & - & $\begin{array}{l}5.303^{* * *} \\
(0.577)\end{array}$ & - \\
\hline Married & $\begin{array}{l}0.0388 \\
(0.0367)\end{array}$ & $\begin{array}{l}-0.0740 \\
(0.106)\end{array}$ & $\begin{array}{l}1.114 \\
(1.409)\end{array}$ & $\begin{array}{l}1.681 \\
(3.191)\end{array}$ \\
\hline Partnered & $\begin{array}{l}0.0633 \\
(0.0431)\end{array}$ & $\begin{array}{l}-0.0703 \\
(0.110)\end{array}$ & $\begin{array}{l}2.321 \\
(1.808)\end{array}$ & $\begin{array}{l}2.034 \\
(3.339)\end{array}$ \\
\hline No spouse & $\begin{array}{l}0.0381 \\
(0.0371)\end{array}$ & $\begin{array}{l}-0.00676 \\
(0.101)\end{array}$ & $\begin{array}{l}1.929 \\
(1.414)\end{array}$ & $\begin{array}{l}3.073 \\
(3.023)\end{array}$ \\
\hline $\begin{array}{l}\text { Household } \\
\text { income }\end{array}$ & $\begin{array}{l}-6.77 e-05 \\
(0.000802)\end{array}$ & $\begin{array}{l}0.00106 \\
(0.00130)\end{array}$ & $\begin{array}{l}-0.00979 \\
(0.0415)\end{array}$ & $\begin{array}{l}0.00662 \\
(0.0393)\end{array}$ \\
\hline $\begin{array}{l}\text { Years of } \\
\text { education }\end{array}$ & $\begin{array}{l}-0.00696 * * * \\
(0.00254)\end{array}$ & - & $\begin{array}{l}-0.239 * * \\
(0.118)\end{array}$ & - \\
\hline Managerial & $\begin{array}{l}0.00255 \\
(0.0247)\end{array}$ & $\begin{array}{l}0.0133 \\
(0.0576)\end{array}$ & $\begin{array}{l}0.0811 \\
(0.917)\end{array}$ & $\begin{array}{l}2.008 \\
(1.713)\end{array}$ \\
\hline Administrative & $\begin{array}{l}0.00924 \\
(0.0244)\end{array}$ & $\begin{array}{l}0.0673 \\
(0.0640)\end{array}$ & $\begin{array}{l}0.938 \\
(0.879)\end{array}$ & $\begin{array}{l}2.333 \\
(1.944)\end{array}$ \\
\hline Sales & $\begin{array}{l}0.00565 \\
(0.0260)\end{array}$ & $\begin{array}{l}-0.0676 \\
(0.0584)\end{array}$ & $\begin{array}{l}2.370 * * \\
(1.029)\end{array}$ & $\begin{array}{l}2.832 \\
(1.739)\end{array}$ \\
\hline Mechanical & $\begin{array}{l}-0.00346 \\
(0.0265)\end{array}$ & $\begin{array}{l}-0.0950 \\
(0.0613)\end{array}$ & $\begin{array}{l}2.177^{* *} \\
(1.091)\end{array}$ & $\begin{array}{l}1.022 \\
(1.835)\end{array}$ \\
\hline Service & $\begin{array}{l}0.00998 \\
(0.0245)\end{array}$ & $\begin{array}{l}0.0447 \\
(0.0630)\end{array}$ & $\begin{array}{l}1.160 \\
(0.877)\end{array}$ & $\begin{array}{l}3.477^{*} \\
(1.899)\end{array}$ \\
\hline Operator & $\begin{array}{l}0.0356 \\
(0.0247)\end{array}$ & $\begin{array}{l}-0.0208 \\
(0.0618)\end{array}$ & $\begin{array}{l}2.637 * * * \\
(0.986)\end{array}$ & $\begin{array}{l}2.041 \\
(1.851)\end{array}$ \\
\hline Farm & $\begin{array}{l}0.00998 \\
(0.0407)\end{array}$ & $\begin{array}{l}-0.0743 \\
(0.0866)\end{array}$ & $\begin{array}{l}-3.270^{* *} \\
(1.476)\end{array}$ & $\begin{array}{l}1.415 \\
(2.673)\end{array}$ \\
\hline Year 1996 & $\begin{array}{l}-0.0457 * * * \\
(0.0132)\end{array}$ & $\begin{array}{l}-0.0863 * * \\
(0.0418)\end{array}$ & $\begin{array}{l}-0.735 \\
(0.664)\end{array}$ & $\begin{array}{l}-1.668 \\
(1.266)\end{array}$ \\
\hline Year 1998 & $\begin{array}{l}-0.0721^{* * * *} \\
(0.0161)\end{array}$ & $\begin{array}{l}-0.141^{*} \\
(0.0775)\end{array}$ & $\begin{array}{l}-3.052^{* * * *} \\
(0.774)\end{array}$ & $\begin{array}{l}-4.644^{* *} \\
(2.341)\end{array}$ \\
\hline Year 2000 & $\begin{array}{l}-0.0821^{* * *} \\
(0.0195)\end{array}$ & $\begin{array}{l}-0.192 * \\
(0.115)\end{array}$ & $\begin{array}{l}-2.934 * * * \\
(0.838)\end{array}$ & $\begin{array}{l}-5.741^{*} \\
(3.472)\end{array}$ \\
\hline Year 2002 & $\begin{array}{l}-0.0837 * * * \\
(0.0242)\end{array}$ & $\begin{array}{l}-0.231 \\
(0.157)\end{array}$ & $\begin{array}{l}-4.363^{* * * *} \\
(0.988)\end{array}$ & $\begin{array}{l}-8.598^{*} \\
(4.734)\end{array}$ \\
\hline Year 2004 & $-0.114 * * *$ & -0.292 & $-5.218 * * *$ & $-10.58 *$ \\
\hline
\end{tabular}




\begin{tabular}{l|llll} 
& $(0.0306)$ & $(0.195)$ & $(1.068)$ & $(5.867)$ \\
Constant & 0.388 & -0.647 & 33.64 & 58.45 \\
& $(0.899)$ & $(1.529)$ & $(36.17)$ & $(46.18)$ \\
\hline Observations & 3,618 & 3,618 & 3,297 & 3,297 \\
$\mathrm{~N}$ & & 1,039 & & 890 \\
$\mathrm{R}$-squared & 0.026 & 0.069 & 0.141 & 0.100 \\
\hline
\end{tabular}

Robust standard errors in parentheses

*** $\mathrm{p}<0.01, * * \mathrm{p}<0.05, * \mathrm{p}<0.1$

${ }^{a}$ Lagged smokers are defined to be persons who reported smoking at the previous interview wave. 
Table 6: Effect of job stress on ever-smokers and lagged quitters ${ }^{a}$

\begin{tabular}{|c|c|c|c|c|c|c|}
\hline & \multicolumn{4}{|l|}{ Ever smoker } & \multicolumn{2}{|c|}{ Lagged quitter } \\
\hline & $\begin{array}{l}\text { Smoking } \\
\text { status } \\
\text { OLS }\end{array}$ & $\begin{array}{l}\text { Smoking } \\
\text { status } \\
\text { FE }\end{array}$ & $\begin{array}{l}\text { Num of } \\
\text { cigarettes } \\
\text { OLS }\end{array}$ & $\begin{array}{l}\text { Num of } \\
\text { cigarettes } \\
\text { FE }\end{array}$ & $\begin{array}{l}\text { Smoking } \\
\text { status } \\
\text { OLS }\end{array}$ & $\begin{array}{l}\text { Smoking } \\
\text { status } \\
\text { FE }\end{array}$ \\
\hline High stress & $\begin{array}{l}0.0413^{* * *} \\
(0.00979)\end{array}$ & $\begin{array}{l}0.0175 * * * \\
(0.00646)\end{array}$ & $\begin{array}{l}1.352 * * * \\
(0.482)\end{array}$ & $\begin{array}{l}1.276^{* * *} \\
(0.424)\end{array}$ & $\begin{array}{l}0.00317 \\
(0.00462)\end{array}$ & $\begin{array}{l}-0.000199 \\
(0.00505)\end{array}$ \\
\hline $\begin{array}{l}\text { Observations } \\
\mathrm{N} \\
\mathrm{R} \text {-squared }\end{array}$ & $\begin{array}{l}17,043 \\
0.068\end{array}$ & $\begin{array}{l}17,043 \\
3,825 \\
0.043\end{array}$ & $\begin{array}{l}6,173 \\
0.145\end{array}$ & $\begin{array}{l}6,173 \\
1,416 \\
0.118\end{array}$ & $\begin{array}{l}7,951 \\
0.004\end{array}$ & $\begin{array}{l}7,951 \\
2,004 \\
0.005\end{array}$ \\
\hline
\end{tabular}

Robust standard errors in parentheses

$* * * \mathrm{p}<0.01, * * \mathrm{p}<0.05, * \mathrm{p}<0.1$

${ }^{a}$ Lagged quitters are defined as smoker who reported having quit smoking by the previous interview wave. Ever smokers are those who have reported smoking sometime in their life. 
Table 7: Mediating factors for lagged smokers

\begin{tabular}{|c|c|c|c|c|}
\hline & Baseline & Risk tolerance & Financial planning & Cognition \\
\hline High stress & $\begin{array}{l}0.0262^{*} \\
(0.0135)\end{array}$ & $\begin{array}{l}0.0268 * * \\
(0.0135)\end{array}$ & $\begin{array}{l}0.0268^{* *} \\
(0.0134)\end{array}$ & $\begin{array}{l}0.0262^{*} \\
(0.0135)\end{array}$ \\
\hline Risk - a third & & $\begin{array}{l}0.0297 \\
(0.0781)\end{array}$ & & \\
\hline Risk - a fifth & & $\begin{array}{l}-0.0774 \\
(0.0863)\end{array}$ & & \\
\hline Risk - no change & & $\begin{array}{l}0.0213 \\
(0.0582)\end{array}$ & & \\
\hline Risk missing & & $\begin{array}{l}-0.00601 \\
(0.0577)\end{array}$ & & \\
\hline $\begin{array}{l}\text { Planning - next } \\
\text { year }\end{array}$ & & & $\begin{array}{l}-0.0848 * \\
(0.0512)\end{array}$ & \\
\hline $\begin{array}{l}\text { Planning }- \text { next } \\
\text { few years }\end{array}$ & & & $\begin{array}{l}-0.0278 \\
(0.0399)\end{array}$ & \\
\hline Planning - next 5 & & & $-0.127 * * *$ & \\
\hline to 10 years & & & $(0.0441)$ & \\
\hline $\begin{array}{l}\text { Planning - longer } \\
\text { than } 10 \text { years }\end{array}$ & & & $\begin{array}{l}-0.121^{*} \\
(0.0713)\end{array}$ & \\
\hline Planning missing & & & $\begin{array}{l}-0.0709 * \\
(0.0364)\end{array}$ & \\
\hline Cognition score & & & & $\begin{array}{l}-0.000148 \\
(0.00206)\end{array}$ \\
\hline Cognition missing & & & & $\begin{array}{l}-0.00307 \\
(0.0368)\end{array}$ \\
\hline Age & $\begin{array}{l}0.0218 \\
(0.0302)\end{array}$ & $\begin{array}{l}0.0198 \\
(0.0306)\end{array}$ & $\begin{array}{l}0.0254 \\
(0.0307)\end{array}$ & $\begin{array}{l}0.0218 \\
(0.0302)\end{array}$ \\
\hline Age squared & $\begin{array}{l}-0.000196 \\
(0.000253)\end{array}$ & $\begin{array}{l}-0.000178 \\
(0.000256)\end{array}$ & $\begin{array}{l}-0.000226 \\
(0.000257)\end{array}$ & $\begin{array}{l}-0.000196 \\
(0.000253)\end{array}$ \\
\hline Black & $\begin{array}{l}-0.0270 * \\
(0.0162)\end{array}$ & $\begin{array}{l}-0.0267^{*} \\
(0.0162)\end{array}$ & $\begin{array}{l}-0.0276^{*} \\
(0.0162)\end{array}$ & $\begin{array}{l}-0.0270 * \\
(0.0163)\end{array}$ \\
\hline Other race & $\begin{array}{l}-0.0456 \\
(0.0334)\end{array}$ & $\begin{array}{l}-0.0457 \\
(0.0331)\end{array}$ & $\begin{array}{l}-0.0479 \\
(0.0330)\end{array}$ & $\begin{array}{l}-0.0456 \\
(0.0334)\end{array}$ \\
\hline Male & $\begin{array}{l}-0.0232 * \\
(0.0130)\end{array}$ & $\begin{array}{l}-0.0231^{*} \\
(0.0130)\end{array}$ & $\begin{array}{l}-0.0220 * \\
(0.0130)\end{array}$ & $\begin{array}{l}-0.0233^{*} \\
(0.0131)\end{array}$ \\
\hline Married & $\begin{array}{l}0.0388 \\
(0.0367)\end{array}$ & $\begin{array}{l}0.0399 \\
(0.0366)\end{array}$ & $\begin{array}{l}0.0378 \\
(0.0365)\end{array}$ & $\begin{array}{l}0.0389 \\
(0.0367)\end{array}$ \\
\hline Partnered & $\begin{array}{l}0.0633 \\
(0.0431)\end{array}$ & $\begin{array}{l}0.0641 \\
(0.0432)\end{array}$ & $\begin{array}{l}0.0604 \\
(0.0430)\end{array}$ & $\begin{array}{l}0.0634 \\
(0.0432)\end{array}$ \\
\hline No spouse & $\begin{array}{l}0.0381 \\
(0.0371)\end{array}$ & $\begin{array}{l}0.0386 \\
(0.0370)\end{array}$ & $\begin{array}{l}0.0352 \\
(0.0370)\end{array}$ & $\begin{array}{l}0.0382 \\
(0.0371)\end{array}$ \\
\hline Household income & $\begin{array}{l}-6.77 \mathrm{e}-05 \\
(0.000802)\end{array}$ & $\begin{array}{l}-7.81 \mathrm{e}-05 \\
(0.000803)\end{array}$ & $\begin{array}{l}9.11 \mathrm{e}-05 \\
(0.000810)\end{array}$ & $\begin{array}{l}-6.56 \mathrm{e}-05 \\
(0.000801)\end{array}$ \\
\hline Years of education & $\begin{array}{l}-0.00696^{* * *} \\
(0.00254)\end{array}$ & $\begin{array}{l}-0.00691^{* * *} \\
(0.00256)\end{array}$ & $\begin{array}{l}-0.00677^{* * *} \\
(0.00254)\end{array}$ & $\begin{array}{l}-0.00694 * * * \\
(0.00258)\end{array}$ \\
\hline
\end{tabular}




\begin{tabular}{|c|c|c|c|c|}
\hline Managerial & $\begin{array}{l}0.00255 \\
(0.0247)\end{array}$ & $\begin{array}{l}0.00150 \\
(0.0247)\end{array}$ & $\begin{array}{l}0.000529 \\
(0.0246)\end{array}$ & $\begin{array}{l}0.00247 \\
(0.0248)\end{array}$ \\
\hline \multirow[t]{2}{*}{ Administrative } & 0.00924 & 0.00811 & 0.00972 & 0.00917 \\
\hline & $(0.0244)$ & $(0.0244)$ & $(0.0244)$ & $(0.0245)$ \\
\hline \multirow[t]{2}{*}{ Sales } & 0.00565 & 0.00423 & 0.00501 & 0.00557 \\
\hline & $(0.0260)$ & $(0.0260)$ & $(0.0259)$ & $(0.0260)$ \\
\hline \multirow[t]{2}{*}{ Mechanical } & -0.00346 & -0.00392 & -0.00349 & -0.00354 \\
\hline & $(0.0265)$ & $(0.0265)$ & $(0.0264)$ & $(0.0265)$ \\
\hline \multirow[t]{2}{*}{ Service } & 0.00998 & 0.00973 & 0.0115 & 0.00984 \\
\hline & $(0.0245)$ & $(0.0245)$ & $(0.0245)$ & $(0.0247)$ \\
\hline \multirow[t]{2}{*}{ Operator } & 0.0356 & 0.0352 & 0.0344 & 0.0355 \\
\hline & $(0.0247)$ & $(0.0246)$ & $(0.0246)$ & $(0.0248)$ \\
\hline \multirow[t]{2}{*}{ Farm } & 0.00998 & 0.00936 & 0.0112 & 0.00979 \\
\hline & $(0.0407)$ & $(0.0407)$ & $(0.0408)$ & $(0.0408)$ \\
\hline \multirow[t]{2}{*}{ Year 1996} & $-0.0457 * * *$ & $-0.0458 * * *$ & $-0.0459 * * *$ & $-0.0464^{* *}$ \\
\hline & $(0.0132)$ & $(0.0132)$ & $(0.0132)$ & $(0.0228)$ \\
\hline \multirow[t]{2}{*}{ Year 1998} & $-0.0721 * * *$ & $-0.0736 * * *$ & $-0.0718 * * *$ & $-0.0727 * * *$ \\
\hline & $(0.0161)$ & $(0.0162)$ & $(0.0162)$ & $(0.0240)$ \\
\hline \multirow[t]{2}{*}{ Year 2000} & $-0.0821 * * *$ & $-0.0843^{* * *}$ & $-0.0827^{* * *}$ & $-0.0828 * * *$ \\
\hline & (0.0195) & $(0.0198)$ & $(0.0198)$ & $(0.0269)$ \\
\hline \multirow[t]{2}{*}{ Year 2002} & $-0.0837 * * *$ & $-0.0909 * * *$ & $-0.0824 * * *$ & $-0.0844 * * *$ \\
\hline & $(0.0242)$ & $(0.0304)$ & $(0.0297)$ & $(0.0308)$ \\
\hline \multirow[t]{2}{*}{ Year 2004} & $-0.114 * * *$ & $-0.116 * * *$ & $-0.118 * * *$ & $-0.115^{* * *}$ \\
\hline & $(0.0306)$ & $(0.0307)$ & $(0.0396)$ & $(0.0358)$ \\
\hline \multirow[t]{2}{*}{ Constant } & 0.388 & 0.450 & 0.352 & 0.390 \\
\hline & (0.899) & $(0.917)$ & $(0.918)$ & $(0.900)$ \\
\hline Observations & 3,618 & 3,618 & 3,618 & 3,618 \\
\hline R-squared & 0.026 & 0.027 & 0.030 & 0.026 \\
\hline
\end{tabular}

Robust standard errors in parentheses *** $\mathrm{p}<0.01,{ }^{*} * \mathrm{p}<0.05,{ }^{*} \mathrm{p}<0.1$ 
Table 8: Accounting for attrition (fixed effects regression)

\begin{tabular}{|c|c|c|c|c|c|}
\hline & $\begin{array}{l}\text { Smoking } \\
\text { status } \\
\text { Lagged } \\
\text { smokers } \\
\end{array}$ & $\begin{array}{l}\text { Num of } \\
\text { cigarettes } \\
\text { Lagged } \\
\text { smokers }\end{array}$ & $\begin{array}{l}\text { Smoking } \\
\text { status } \\
\text { Ever } \\
\text { smokers } \\
\end{array}$ & $\begin{array}{l}\text { Num of } \\
\text { cigarettes } \\
\text { Ever } \\
\text { smokers }\end{array}$ & $\begin{array}{l}\text { Smoking } \\
\text { status } \\
\text { Lagged } \\
\text { quitters }\end{array}$ \\
\hline High stress & $\begin{array}{l}0.0474^{* *} \\
(0.0184)\end{array}$ & $\begin{array}{l}1.863 * * * \\
(0.613)\end{array}$ & $\begin{array}{l}0.0203^{* * * *} \\
(0.00626)\end{array}$ & $\begin{array}{l}1.233 * * * \\
(0.416)\end{array}$ & $\begin{array}{l}0.00186 \\
(0.00450)\end{array}$ \\
\hline Part time & $\begin{array}{l}-0.0187 \\
(0.0176)\end{array}$ & $\begin{array}{l}0.468 \\
(0.584)\end{array}$ & $\begin{array}{l}-0.00123 \\
(0.00576)\end{array}$ & $\begin{array}{l}-0.407 \\
(0.398)\end{array}$ & $\begin{array}{l}-0.00307 \\
(0.00392)\end{array}$ \\
\hline Retired & $\begin{array}{l}-0.0931^{* *} \\
(0.0412)\end{array}$ & $\begin{array}{l}0.962 \\
(1.345)\end{array}$ & $\begin{array}{l}-0.00989 \\
(0.0104)\end{array}$ & $\begin{array}{l}-0.611 \\
(0.841)\end{array}$ & $\begin{array}{l}-0.00144 \\
(0.00685)\end{array}$ \\
\hline Not working & $\begin{array}{l}-0.113 * * \\
(0.0487)\end{array}$ & $\begin{array}{l}1.239 \\
(1.604)\end{array}$ & $\begin{array}{l}-0.0175 \\
(0.0140)\end{array}$ & $\begin{array}{l}-0.627 \\
(0.999)\end{array}$ & $\begin{array}{l}-0.00143 \\
(0.0109)\end{array}$ \\
\hline Age & $\begin{array}{l}0.0513 \\
(0.0336)\end{array}$ & $\begin{array}{l}-1.389 \\
(1.115)\end{array}$ & $\begin{array}{l}-0.00763 \\
(0.00908)\end{array}$ & $\begin{array}{l}-0.239 \\
(0.638)\end{array}$ & $\begin{array}{l}-0.00198 \\
(0.00720)\end{array}$ \\
\hline Age squared & $\begin{array}{l}-0.000357 \\
(0.000239)\end{array}$ & $\begin{array}{l}0.0132 * \\
(0.00792)\end{array}$ & $\begin{array}{l}4.47 e-05 \\
(6.00 e-05)\end{array}$ & $\begin{array}{l}0.00378 \\
(0.00433)\end{array}$ & $\begin{array}{l}-3.30 \mathrm{e}-05 \\
(4.85 \mathrm{e}-05)\end{array}$ \\
\hline Married & $\begin{array}{l}-0.117 \\
(0.101)\end{array}$ & $\begin{array}{l}-0.0564 \\
(3.305)\end{array}$ & $\begin{array}{l}0.0182 \\
(0.0354)\end{array}$ & $\begin{array}{l}-0.167 \\
(2.089)\end{array}$ & $\begin{array}{l}-0.0302 \\
(0.0318)\end{array}$ \\
\hline Partnered & $\begin{array}{l}-0.0550 \\
(0.104)\end{array}$ & $\begin{array}{l}0.818 \\
(3.426)\end{array}$ & $\begin{array}{l}0.0282 \\
(0.0367)\end{array}$ & $\begin{array}{l}-0.585 \\
(2.174)\end{array}$ & $\begin{array}{l}-0.0219 \\
(0.0324)\end{array}$ \\
\hline No spouse & $\begin{array}{l}-0.0794 \\
(0.0972)\end{array}$ & $\begin{array}{l}1.095 \\
(3.181)\end{array}$ & $\begin{array}{l}0.0552 \\
(0.0348)\end{array}$ & $\begin{array}{l}0.511 \\
(2.033)\end{array}$ & $\begin{array}{l}-0.00818 \\
(0.0314)\end{array}$ \\
\hline $\begin{array}{l}\text { Household } \\
\text { income }\end{array}$ & $\begin{array}{l}0.00139 \\
(0.00121)\end{array}$ & $\begin{array}{l}0.0138 \\
(0.0406)\end{array}$ & $\begin{array}{l}-0.000331 \\
(0.000384)\end{array}$ & $\begin{array}{l}0.0282 \\
(0.0303)\end{array}$ & $\begin{array}{l}-0.000413 \\
(0.000262)\end{array}$ \\
\hline Managerial & $\begin{array}{l}-0.0615 \\
(0.0457)\end{array}$ & $\begin{array}{l}1.676 \\
(1.487)\end{array}$ & $\begin{array}{l}0.00408 \\
(0.0116)\end{array}$ & $\begin{array}{l}0.906 \\
(0.939)\end{array}$ & $\begin{array}{l}0.00604 \\
(0.00766)\end{array}$ \\
\hline Administrative & $\begin{array}{l}-0.0349 \\
(0.0463)\end{array}$ & $\begin{array}{l}1.146 \\
(1.528)\end{array}$ & $\begin{array}{l}0.0378^{* * *} \\
(0.0125)\end{array}$ & $\begin{array}{l}0.883 \\
(0.946)\end{array}$ & $\begin{array}{l}-0.00563 \\
(0.00856)\end{array}$ \\
\hline Sales & $\begin{array}{l}-0.120 * * \\
(0.0466)\end{array}$ & $\begin{array}{l}2.644^{*} \\
(1.517)\end{array}$ & $\begin{array}{l}-0.000465 \\
(0.0128)\end{array}$ & $\begin{array}{l}1.587 \\
(0.970)\end{array}$ & $\begin{array}{l}0.00292 \\
(0.00871)\end{array}$ \\
\hline Mechanical & $\begin{array}{l}-0.0927^{* *} \\
(0.0460)\end{array}$ & $\begin{array}{l}3.092 * * \\
(1.507)\end{array}$ & $\begin{array}{l}0.00723 \\
(0.0128)\end{array}$ & $\begin{array}{l}1.733^{*} \\
(0.966)\end{array}$ & $\begin{array}{l}0.00258 \\
(0.00892)\end{array}$ \\
\hline Service & $\begin{array}{l}-0.0156 \\
(0.0454)\end{array}$ & $\begin{array}{l}1.034 \\
(1.488)\end{array}$ & $\begin{array}{l}0.0395^{* * *} \\
(0.0124)\end{array}$ & $\begin{array}{l}1.071 \\
(0.923)\end{array}$ & $\begin{array}{l}-0.00113 \\
(0.00866)\end{array}$ \\
\hline Operator & $\begin{array}{l}-0.0580 \\
(0.0446)\end{array}$ & $\begin{array}{l}3.050 * * \\
(1.455)\end{array}$ & $\begin{array}{l}0.0157 \\
(0.0120)\end{array}$ & $\begin{array}{l}0.712 \\
(0.919)\end{array}$ & $\begin{array}{l}-0.00473 \\
(0.00836)\end{array}$ \\
\hline Farm & $\begin{array}{l}-0.109 * \\
(0.0664)\end{array}$ & $\begin{array}{l}1.238 \\
(2.206)\end{array}$ & $\begin{array}{l}0.00560 \\
(0.0198)\end{array}$ & $\begin{array}{l}-0.0517 \\
(1.434)\end{array}$ & $\begin{array}{l}0.00870 \\
(0.0136)\end{array}$ \\
\hline Year 1994 & & & $\begin{array}{l}-0.0337^{* * *} \\
(0.0115)\end{array}$ & $\begin{array}{l}-0.429 \\
(0.781)\end{array}$ & \\
\hline Year 1996 & $\begin{array}{l}-0.0864 * * \\
(0.0373)\end{array}$ & $\begin{array}{l}-2.004 \\
(1.245)\end{array}$ & $\begin{array}{l}-0.0424 * \\
(0.0218)\end{array}$ & $\begin{array}{l}-3.455^{* *} \\
(1.482)\end{array}$ & $\begin{array}{l}0.0221^{* *} \\
(0.00884)\end{array}$ \\
\hline Year 1998 & $\begin{array}{l}-0.150 * * \\
(0.0682)\end{array}$ & $\begin{array}{l}-4.950 * * \\
(2.268)\end{array}$ & $\begin{array}{l}-0.0694^{* *} \\
(0.0317)\end{array}$ & $\begin{array}{l}-5.986 * * * \\
(2.154)\end{array}$ & $\begin{array}{l}0.0271^{*} \\
(0.0159)\end{array}$ \\
\hline Year 2000 & $\begin{array}{l}-0.204^{* *} \\
(0.101)\end{array}$ & $\begin{array}{l}-6.344^{*} \\
(3.353)\end{array}$ & $\begin{array}{l}-0.0887 * * \\
(0.0421)\end{array}$ & $\begin{array}{l}-7.759 * * * \\
(2.861)\end{array}$ & $\begin{array}{l}0.0372 \\
(0.0236)\end{array}$ \\
\hline Year 2002 & $\begin{array}{l}-0.249 * \\
(0.138)\end{array}$ & $\begin{array}{l}-9.713^{* *} \\
(4.564)\end{array}$ & $\begin{array}{l}-0.105^{*} \\
(0.0536)\end{array}$ & $\begin{array}{l}-10.49 * * * \\
(3.644)\end{array}$ & $\begin{array}{l}0.0511 \\
(0.0321)\end{array}$ \\
\hline Year 2004 & $\begin{array}{l}-0.280^{*} \\
(0.170)\end{array}$ & $\begin{array}{l}-10.31 * \\
(5.643)\end{array}$ & $\begin{array}{l}-0.120^{*} \\
(0.0640)\end{array}$ & $\begin{array}{l}-11.93^{* * * *} \\
(4.344)\end{array}$ & $\begin{array}{l}0.0631 \\
(0.0398)\end{array}$ \\
\hline
\end{tabular}




\begin{tabular}{l|lllll} 
Constant & -0.620 & 55.47 & $0.632 *$ & 20.41 & 0.261 \\
& $(1.301)$ & $(43.18)$ & $(0.372)$ & $(25.49)$ & $(0.294)$ \\
\hline Observations & 4,497 & 4,122 & 22,974 & 8,327 & 10,134 \\
$\mathrm{~N}$ & 1,039 & 890 & 3,825 & 1,416 & 2,004 \\
R-squared & 0.078 & 0.117 & 0.059 & 0.156 & 0.004 \\
\hline *** $<<0.01, * * \mathrm{p}<0.05, * \mathrm{p}<0.1$ & & & &
\end{tabular}

Standard errors in parentheses 
Table 9: Robustness Checks

Effect of Stress on Smoking Status of Lagged Smokers- Fixed Effects Regression

\begin{tabular}{|c|c|c|c|c|c|}
\hline & $(1)$ & $(2)$ & (3) & (4) & (5) \\
\hline Stress & $\begin{array}{l}0.0598 * * * \\
(0.0197)\end{array}$ & $\begin{array}{l}0.0664^{* * *} \\
(0.0193)\end{array}$ & $\begin{array}{l}0.0613^{* * *} \\
(0.0195)\end{array}$ & $\begin{array}{l}0.0570^{* * *} \\
(0.0220)\end{array}$ & $\begin{array}{l}0.0554 * * * \\
(0.0198)\end{array}$ \\
\hline Poor health & & $\begin{array}{l}-0.0497 \\
(0.0490)\end{array}$ & & & \\
\hline Fair health & & $\begin{array}{l}0.0261 \\
(0.0302)\end{array}$ & & & \\
\hline Good health & & $\begin{array}{l}0.0188 \\
(0.0244)\end{array}$ & & & \\
\hline Very good health & & $\begin{array}{l}0.0365^{*} \\
(0.0219)\end{array}$ & & & \\
\hline ADL & & $\begin{array}{l}-0.0173 \\
(0.0206)\end{array}$ & & & \\
\hline New health condition & & $\begin{array}{l}-0.0904 * * * \\
(0.0128)\end{array}$ & & & \\
\hline CESD score & $\begin{array}{l}-0.00423 \\
(0.00473)\end{array}$ & & & & \\
\hline Job tenure & & & $\begin{array}{l}-0.000861 \\
(0.00109)\end{array}$ & $\begin{array}{l}-0.00178 \\
(0.00148)\end{array}$ & \\
\hline Pressure to retire & & & & $\begin{array}{l}0.0235^{*} \\
(0.0140)\end{array}$ & \\
\hline $\begin{array}{l}\text { Preference to younger } \\
\text { workers }\end{array}$ & & & & $\begin{array}{l}0.00347 \\
(0.0132)\end{array}$ & \\
\hline Parental death & & & & & $\begin{array}{l}-0.0121 \\
(0.0222)\end{array}$ \\
\hline Constant & $\begin{array}{l}-0.977 \\
(1.608) \\
\end{array}$ & $\begin{array}{l}-0.545 \\
(1.514) \\
\end{array}$ & $\begin{array}{l}-0.689 \\
(1.532)\end{array}$ & $\begin{array}{l}-0.344 \\
(1.845) \\
\end{array}$ & $\begin{array}{l}-0.742 \\
(1.555)\end{array}$ \\
\hline Observations & 3,359 & 3,617 & 3,611 & 2,679 & 3,506 \\
\hline Number of persons & 999 & 1,039 & 1,039 & 867 & 1,022 \\
\hline R-squared & 0.067 & 0.091 & 0.070 & 0.076 & 0.067 \\
\hline
\end{tabular}

Standard errors in parentheses

$* * * \mathrm{p}<0.01, * * \mathrm{p}<0.05, * \mathrm{p}<0.1$

Additional controls include age, age squared, married, partnered, no spouse, household income, occupation fixed effects and wave dummies. 